\title{
PROSTITUTE OR FIRST APOSTLE? CRITICAL FEMINIST INTERPRETATION OF JOHN 4: 1-42 OVER THE FIGURE OF THE SAMARITAN WOMAN AT JACOB'S WELL
}

\author{
ASNATH NIWA NATAR* \\ Faculty of Theology, Universitas Kristen Duta Wacana, Yogyakarta
}

\section{Abstract}

The Bible is indeed written in a patriarchal culture and someone finds it desperate to search for the Bible texts that support equality as it provides insufficient passages of equality between men and women. Nonetheless, to use the feminist perspectives is pivotal in searching for equality in reading the Bible texts. It helps people to learn from the efforts made by women in the Bible in order to get out of their oppression and to not take for granted of their miserable situation. Thus in this paper, the author makes a reinterpretation effort on the text of John 4, 1- 42 which has been interpreted in gender bias. The interpretation uses the historical-critical method with a hermeneutic approach to investigation (suspicion) from a feminist perspective. Hermeneutic investigative approach is an approach that reads the text critically and with assumptions (initial suspicion) about the elements of power relations that exist in the text that are dominative and investigates the text. This new approach can result in a new understanding and appreciation of the figures and actions of the Samaritan woman who has been seen as a prostitute and a sinful woman.

Alkitab memang ditulis dalam budaya patriarkal dan bisa membuat orang putus asa bila orang ingin mencari sebanyak-banyakn-

\footnotetext{
* Corresponding author: Jl. Dr. Wahidin Sudirohusodo No.5-25, Kotabaru, Gondokusuman, Yogyakarta, 55224. E-mail: asnathnatar@yahoo.com.
} 
ya teks Alkitab untuk mendukung kesetaraan antara laki-laki dan perempuan. Namun hal yang penting sebenarnya adalah bagaimana menggunakan perspektif feminis dalam membaca teks Alkitab untuk belajar dari upaya-upaya yang dilakukan oleh perempuan dalam Alkitab dalam rangka keluar dari ketertindasan mereka. Upaya-upaya ini penting untuk tidak menerima begitu saja keadaan mereka. Penulis melakukan upaya penafsiran ulang terhadap teks Yohanes 4:1-42 yang selama ini ditafsirkan secara bias gender. Tafsiran dilakukan dengan menggunakan metode historis kritis dengan pendekatan hermeneutik investigasi (kecurigaan) dari perspektif feminis. Pendekatan hermeneutik investigasi adalah sebuah pendekatan yang membaca teks secara kritis dan dengan asumsi (kecurigaan awal) tentang unsur relasi kekuasaan yang ada dalam teks yang bersifat dominatif serta melakukan investigasi terhadap teks tersebut. Pendekatan yang baru ini dapat menghasilkan pemahaman dan penghargaan yang baru terhadap figur dan tindakan perempuan Samaria yang selama ini dilihat sebagai perempuan pelacur dan berdosa.

Keywords: apostles; critical interpretation; feminist; masculine; patriarchy; women.

\section{Introduction}

Injustice and discrimination against women have occurred for centuries even since the biblical era. This is inseparable from the influence of patriarchal and kyriarchic cultures that affect culture and society. This condition is getting stronger because it is taught and passed down through generations embracing their own cultures and religions. It results in the difficulty of changing and eliminating that understanding.

Almost all the rules in the Bible are made and addressed to men holding the main and dominant role in society. They are the main actors while women only become "extras" or male partner (as fathers, husbands or brothers) who support men's stories (Kristianto 2019, 37). Only a few women play a role 
(sometimes not named), whether as a wife, mother, mother-inlaw, sister, daughter-in-law, daughter or female slave of a man. It is not surprising that the Bible becomes a male story (his story) and not a female story (her story).

The description of women in the Bible is also the result of male construction, in which women are described as being inferior (secondary sexs) than men and are under the power of men. There are many texts that seem to oppress or underestimate women. Not all the contents of the scriptures are good news for women, and not all liberate women. Gender biased texts are used by the church in church teaching and influence attitudes towards women, including the prohibition of women from serving as servants. Some biblical texts imply elements of violence, discrimination and injustice against women, such as: Gen. 16: 1-16; 29: 30-30: 24. The verse states that the main task of women is to give birth to children and please their husbands; Est. 1: 17-22: Warning for women to respect their husbands and not fight like the Wasti Queen, and 1 Cor. 14: 33-35: women must be silent in church meetings.

So, it is not wrong to say that religion or the church has helped oppress women. Mary Daly (Daly 1985), a feminist theologian, sued by leaving the church and leaving the Bible. For her the church and the Bible did not help women to gain freedom and a place that was equal to men. The Bible is not used as a means of deliverance but rather a tool of oppression.

But, actually not all texts in the Bible discriminate and oppress women. There are texts that support women like Gen. 1:27: men and women are images of God. However, andocentric interpretation has used many texts to support the view that women occupy the second position after men, even belonging to men who must submit to and obey them. Not infrequently this is understood as God's will and is also believed by women. 
This situation occurs because for centuries the interpreters of the scriptures were men because only those who were given the authority to learn and teach. Even though an interpretation is strongly influenced by the interpreter with all his interests. The male interpreters use masculine perspectives, which certainly pay more attention and affirm male domination. As a result, women's voices, experiences and interests are ignored, even though the Bible itself has women's voices and experiences, not just men's voices and experiences. For example, the image of God as woman and mother: Witness of women and childbirth (Deut 32:18, Job 38:28), Mother bear (Hos 13: 8), Mother eagle (Deut 32:11 etc., Exodus 19: 4 ), Mother hen (Matt. 23:37, Luke 13:34), Mother bird (Ruth 2:12, Ps. 17: 8, etc., 57: 1, 61: 5, 91: 4). Likewise, it is the description of mother and father (parents) in Deutero and Trito Isaiah 66 and Hosea 11. Interpretation from this masculine perspective has an impact on the marginalization of women in almost all fields, both in society and the church.

In this connection, biblical texts need to be reinterpreted from a feminist perspective, not abandoned or discarded. What was done by Mary Daly, who left the church and did not use the Bible, is a radical step. However, it did not change the situation because the Bible with its biased interpretation would still be used. An important principle is not to abandon or discard the Bible (such as running away) but to deconstruct understanding and interpretations that oppress women and vulnerable groups. The next step is reconstruction, which is interpreting the Bible from a feminist perspective to produce explanations that see women and men as equally valuable, equal and have rights and obligations in society. In other words, biblical interpretation is not an instrument of oppression, but an instrument of strength 
and liberation for women and society (Listijabudi 2019). ${ }^{2}$ Here two liberations occur, first, the liberation of the Bible from sexist and andocentric interpretation. Second, liberation for women and those who are weak. This liberation is not only from the dualism of men and women, but also liberation from a patriarchal structure which includes discrimination, subordination, injustice and oppression (racist, sexist, class and colonial; Russel 1998, $11)$.

In an effort to reinterpret texts that have been interpreted as gender biased so far, here the author chooses John. 4: 1-42 about the Samaritan woman at Jacob's well (Ashton 2014, 11-12). The selection of this text is based on several considerations.

First, the interpretation so far has seen the Samaritan woman as immoral or prostitute and sinful ${ }^{4}$, while the text itself does

${ }^{2}$ This can be compared to Sugirtharajah's hermeneutic position when he stated that all religions contain and have liberative and oppressive elements. But he put more emphasis on the liberative dimension that can create goodness for social life.

${ }^{3}$ The reason for choosing Yoh. 4: 1-42 as the focused study in this article is based on the middle position of the series of conversations between Jesus and Nicodemus (John 3: 1-21) as representing the Jews of the Pharisees and healing the children of Roman court officials (John 4:46 -54). Nicodemus, Samaria and Rome are three ethnic groups which are often called enemies of the Jews (cf. Sir. 50: 25-26). By looking at this sequence it becomes clear that in the Gospel of John, Jesus 'conversation with the Samaritan women was not intended to discredit them but emphasized the universality of Jesus' mission as explicitly written on John. 1: 10-12, that human acceptance of His coming is to have the power to become children of God, those who believe in His name.

4 The Samaritan woman was not given a name and its origin was also not explained in the Bible. But in John 4: 9 there is a statement that the Jews did not associate with the Samaritans to emphasize a contradiction in the attitude of Jesus that is different from the Jews in general. The conversation that appeared in the passage, especially related to his personal status who had already had five husbands, was a matter of considerable discussion. The question is what is the reason that woman has so many husbands? The interpretations that have emerged so far can only provide explanations of hypotheses associated with Jewish traditions such as the marriage of levirate and its 
not speak so. The assessment is based on Jesus' explicit words stating that he already has five husbands and the man who is with him is not her husband (John 4: 17-18). From that statement comes the picture that Jesus omniscience (omniscience) on the one hand and immoral Samaritan women on the other. Readings that are based only on certain verses and are free from the context and purpose of writing the book certainly can not be maintained. The presence of Jesus at Jacob's well according to the writer of the Gospel of John is not without clear reason and purpose. Jesus' return to Samaria is not only related to His mission into the world but also as evidence that God loves the world, including those categorized as enemies (Gorman 2017, 141-43). And this woman is a smart woman who is used by God to be a witness of Christ for her people.

Second, this text illustrates the active role of a woman even though she lives in a patriarchal society that is discriminatory against women, ethnic groups and surrounding religions. However, this woman dared to speak out and break down all the differences that prevented relations between gender, ethnicity and religion. The figure of a Samaritan woman is important for the struggle of women today in overcoming various discrimination experienced, to dare to speak up and become equal with men.

The interpretation is carried out with a hermeneutic approach to investigation (suspicion) from a critical feminist perspective, from Elisabeth S. Fiorenza (Fiorenza 2001, 175-76). Hermeneutic investigations became a starting point in reading the biblical text to see the patriarchal and andocentric systems that existed in ancient Israeli society. Investigations are carried out by asking critical questions related to patriarchal and andocentric views, and looking for pieces and lines of stories that might be lost, lost or intentionally removed. Through this ap-

position in the law in which a wife cannot divorce a husband. 
proach, the truths of women's reality are touched, revealed and made to share with other truths. In this connection, this article is given the title Prostitute or the First Apostle? The word apostle comes from the Greek Apostolos (masculine) which means messenger, ambassador. So the apostle is someone who is sent with special orders (Kasper 2009, 851). A messenger is sent down for giving testimony about his messenger or preaching the name of God to other nations. This is seen in Acts. 9:15, But the Lord said to him, "Go, because this man is my chosen instrument for proclaiming my name to the Gentiles and the kings and the people of Israel". Or in Acts. 20:21, I always witness to the Jews and the Greeks, so that they repent to God and believe in our Lord, Jesus Christ. The Apostle John in 1 John. 4:14 says, "And we have seen and testified that the Father sent his Son to be the Savior of the world." So the apostle or apostolos is a messenger who has the task of witnessing about Jesus Christ. This means that anyone who is sent can be called an apostle.

The word Apostle is generally applied to men, namely to the twelve disciples of Jesus (Luke 6:13). But furthermore the designation of the Apostles was not only addressed to the twelve disciples of Jesus (later only 11 were left because Judas betrayed Jesus), but also to others, such as Paul, Andronicus and Junia or Jonias, who were considered male, even though he was a women: apostles, missionaries (Rom. 16: 7) (Fiorenza 1995b, 71-75). Thus the office of the Apostle is not only aimed at men, but also at women. Apart from the apostolic title which is generally terminologically given to men, it is clear that the mission in the Gospel of John is the duty of all believers. In this case the Gospel

${ }^{5}$ The word apostle in the title of this paper refers to one of the aims of John's Gospel which is summarized as "missional-incarnational ethos". The dialogue or interaction between Jesus and the Samaritan woman must be seen from the purpose of the Gospel as found in John. 20:21, “... As the Father sent me, so also I send you". 
of John must be read not from gender differences even though those differences still exist in them (Engberg-Pedersen 2017, 85). Besides that, the definition of apostle can also be seen from the text which clearly states the attitude of the Samaritan woman after knowing Jesus. To John 4: 28-20 explained that she went to the city leaving her jar and said to the people there, "Come, look! There was someone who told me everything I had done. Could He be the Christ? The duty of the apostle as usual was defined by this woman. Even extraordinary is that without the command to tell who Jesus was, she immediately carried out the task as an apostle despite indirectly stating that Jesus is the Christ (Marc-Andre and Bonneau 2016, 136).

\section{The Interpretation of John 4:1-42 from Feminist Perspective}

\section{Texts}

1. When the Lord Jesus knew, that the Pharisees had heard, that He had obtained and baptized more disciples than John. 2 . although Jesus himself did not baptize, but His disciples. 3. He left Judea and returned to Galilee. 4. He had to cross Samaria. 5. So he came to a city in Samaria, which was called Sychar, near the land that Jacob had given to his son Joseph. 6. There is Jacob's well. Jesus was very tired from the journey, so He sat by the well. Around twelve o'clock. 7. Then a woman from Samaria came to draw water. Jesus said to her, "Give me a drink". 8. Because His disciples have gone to the city to buy food. 9. Then the Samaritan woman said to Him, "Do you, a Jew, ask me to drink, a Samaritan?" (Because the Jews did not associate with the Samaritans). 10. Jesus answered her, "If you know about the gift of God and who is the one who said to you: Give me drink! Surely you have asked him and he has given you living water." 11. The woman said to Him: "Lord, You have no bucket and this deep well; where did you get the living water? 12. Are You greater than our father Jacob, who gave this well to us and who He drank himself from it, and his children and his livestock?" 13. Jesus answered her, "Whoever drinks this water will thirst again, 14. But whoever drinks water that I 
will give him, he will not thirst for ever. On the contrary the water that I will give him, will become a spring in himself, which continually radiates to eternal life." 15 . The woman said to Him, "Lord, give me that water, so that I will not be thirsty and will not have to come here again to draw water". 16. Jesus said to her: "Go, call your husband and come here". 17. Said the woman: "I have no husband". Jesus said to her: "Exactly what you say, that you do not have a husband, 18. because you already have five husbands and what you have now is not your husband. In this case you were telling the truth". 19. The woman said to Him, "Lord, it is now apparent to me, that You are a prophet. 20. Our ancestors worshiped on this mountain, but you say that Jerusalem is the place where people worship". 21. Jesus said to her: "Believe in me, $\mathrm{O}$ woman, the time will come, that you will worship the Father not on this mountain and not in Jerusalem. 22. You worship what you don't know, we worship what we know , because salvation comes from the Jewish nation 23. But the time will come and it is now, that true worshipers will worship the Father in spirit and truth, because the Father desires such worshipers.24. God is Spirit and whoever worships Him, must worship Him in spirit and in truth." 25. The woman answered Him, "I know that the Messiah will come, also called Christ; when He comes, He will tell us everything." 26. Jesus said to her: "I am he who is speaking with you." 27. At that time His disciples came and they were surprised that He was having a conversation with a woman. But no one says: "What do you want? Or: What do you talk about with her?" 28 . So the woman left her jar and went to the city and said to the people there: 29. "Come, look! There is someone there who tells me everything that I have done. Could it be that Christ?" 30. So they went outside the city and came to Jesus. 31. Meanwhile his disciples invited him, saying: "Rabbi, eat." 32. But He said to them: "There is Me food that you do not know." 33. Then the disciples said to one another: "Has anyone brought anything to Him to eat?" 34. Jesus said to them: "My food is to do the will of the one who sent me and to finish His work. 35. Didn't you say: In four months the harvest is coming? But I say to you: Look around you and look at the fields that yellow and ripe for reaping 36 . Now also the reaper has received his reward and he is gathering fruit for eternal life, 
so that the sower and the reaper rejoice together 37 . Because in this case the proverb is true: One sows and another reaps. 38. I sent you to reap what you did not work for; others tried and you came to reap the fruits of their efforts. " 39 . And many of the Samaritans from that city have believed in him because of the words of the woman, who testified: "He told me everything that I had done." 40. When the Samaritans came to Jesus, they asked Him, so that He stayed with them; and he stayed there two days. 41. And more people came to believe because of his words, 42. and they said to the woman: "We believe, but not because of what you say, because we ourselves have heard him and we know that he is truly true savior of the world."

\section{Contexts}

The stories of women in the Gospel of John are all positively presented. In their relationship with Jesus, their personalities and original characters are very prominent and show an unconventional role. They deal directly with Jesus without the intervention of others, their position is determined by Jesus' call and their love for Him. Women show extraordinary initiative and assertiveness (Sim 2015, 21).

The passage of Joh. 4: 1-42 is the only conversation between Jesus and the Samaritan woman in the entire Gospel and is between (a) Jesus' conversation with Nicodemus, one of the Pharisees' Jewish religious experts and (b) the narrative of healing Roman palace employees's son. Samaritan women according to Jewish tradition, although descended from Jacob, they are considered to be half Jewish. These three groups are ordered together to show that Jesus communicates with those who are considered enemies of Jesus and Jews. ${ }^{6}$ Hostilities with Samaria have been going on for a long time when the kingdom of Israel

${ }^{6}$ This context must be read as an area of the mission to liberate the Gospel of John, where it was not only Jesus (Jewish representation) who was nationally colonized from Rome but also Samaria who experienced Roman and Jewish colonization at the same time. 
was split into two. Jerusalem became the capital of Southern Israel, often called Judah, and Samaria became the capital of Northern Israel, after the reign of King Solomon. In addition to the political aspects, the separation was also considered an apostasy because Samaria had no faith in the true God. Economic aspects were also affected because Judah no longer wanted to consume food and drink from the Samaritans. It was in that area that Jesus stopped alone and met a Samaritan woman, while He told His disciples to find food. It was in this context that the writer of the Gospel of John taught that Jesus also fulfilled the expectations of the Samaritans (people outside Israel) and that He himself showed His power to reconcile the Jews with the long-separated Samaria (Brown 2015, 293-96).

Paying attention to the content of Jesus' conversation with the Samaritan woman, although many things can be developed from narratives such as the theme of living water (Jn 4: 4-15), ethnic relations (Jn 4: 16-18), gender, prophet, geography and Jacob's well. Historically, however, there are three concentrations of all passages, namely (a) ethnic issues, (b) gender and (c) religion (Powery 2015, 163-65).?

\section{Samaritan Woman}

Before interpreting it needs to be explained about the feminist perspective approach. There are various approaches to feminist interpretation of the Bible and one that is quite popular comes from Fiorenza which states, "biblical readings by women, the reading of the Bible as woman, or its interpretations in terms of gender, are not simply identical with a critical feminist read-

${ }^{7}$ From this dominant context it can be explained that the contradiction displayed in the text is something that the reader must pay attention to, both in the past when the Gospel was written and in the present when the text is read. One of the goals of this emphasis is to direct the focus of liberation both to the Samaritan woman herself and to women today. Herein lies the main mission the evangelist intends to put forward. 
ing ... "(Fiorenza 1995a, 154). This approach as proposed by Fiorenza, although it has the support of many interpreters, is not always applicable to the reader. The reason for not following is based on the focus of the struggle of women who transformed the patri-kyriarchic structure by not placing the Scriptures at the center of attention. For this reason, the feminist perspective referred to here is not the end of interpretation but as a test subject to how the text teaches the reader about God revealing himself to humans (Trible 1982, 116-18). (Trible 1982, 116-18). The feminist perspective here does not follow a radical flow but a reformist flow which also struggles to free women from oppression (Day 2002, 151-53). The term of hermeneutic suspicion used here follows Ricour's view with an attitude not to put one's own thoughts into the text but to openly listen to the flow of the text so that the interpretation becomes creative.

The first concern to be expressed from the text is how the Samaritan woman, a foreign woman, voiced in the narrative. This is one of the stories of women in the Bible, where women talk a lot, besides the story of Eve's conversation with the snake in the book of Genesis. The active attitude of this woman can be interpreted as the representative attitude of the Samaritans who were experiencing national oppression from the Assyri people in the past and the Romans in the time of Jesus (Lim 2010, 42-45). Not much can be told about the Samaritan Woman in history. But from this text it can be seen who she is or what and how she is. For this purpose, I used the perspective of Nestor Miguez who in his book Through the Eyes of Another made a difference in the position of Jesus and the Samaritan Woman. Jesus was a Jew from Galilee, a teacher and had students, while this woman was a Samaritan who lived in a small town of Sychar ${ }^{8}$. She is

${ }^{8}$ The city of Sikhar may be another name for Shechem (Gen. 33:18) or even an error in writing, because the word Sikhar has no meaning. In accordance with information from John. 4: 5, that Sychar was near the land 
an ordinary village woman, accustomed to heavy work. Jesus was accustomed to in-depth discussions with priests and Pharisees, while Samaritan women dealt with routine household and family activities such as drawing water from wells. Jesus traveled all over the country on missionary missions and because of that he was known by many people and in many places. While this woman lives in only one village, that may be the only place where she is known by others. Jesus is also called the Lamb of God. Many commentators know this woman as an adulterous woman. Likewise the attitude of many people who learned a lot about Jesus and His actions throughout the ages up to now, for example what He said and did. While this woman, without a name and will only be remembered in the story as a person who has met with Jesus and dialogue with $\mathrm{Him}^{9}$ (Miguez 2004, 334; Beirne 2003, 67-69).

Differences are not only seen in figures but also when they communicate with each other. Jesus spoke with heavenly wisdom, this woman spoke from practical reality. Jesus talked about eternal life, this woman talked about daily tasks. Jesus spoke of living water that came through His presence (John 4:10), this

that Jacob had given to his son Joseph. From Gen. 33:18 it is clear that the land which Jacob bought was Shechem. It was on this land that the bones of Joseph that the Israelites brought from Egypt were buried (Josh. 24:32). Allegedly the land of Shechem became the foot of Mount Gerizim, the holy mountain of the Samaritans, where in this place stood the temple (house of worship) of the Samaritans.

${ }^{9}$ A lot of discussion about the source used by John, because in the synoptic Gospels the narrative of Jesus' conversation with the Samaritan woman do not appear. The question is certainly no longer looking for sources but on the intent and purpose, why the writer of the Gospel of John included this narration in a series of conversations between Jesus and Nicodemus and the healing event of the son of a Roman court official. Is it as interpreted by some experts to open communication with Jewish enemies? Cannot be ascertained. But theologically it can be explained that the primary concern of the gospel writer lies in the natural character of faith and in the essential understanding of discipleship. 
woman spoke of the traditions received from her people. Jesus talked about spiritual truths, women talked about worldly existence. From this it can be seen that they are actually not in dialogue but rather as two people who are conducting monologues in parallel (Miguez 2004, 334). This fundamental difference also changed the method of conversation and directed the woman to get to know Himself more closely. The change arises from Jesus' own desires. He wanted the woman to reevaluate the relationship of a Samaritan with a Jew and re-evaluate his position with whom he spoke (Sturdevant 2015, 113). This is seen in the words of Jesus, "If you know about the gift of God and who is the one who said to you: Give me drink! Surely you have asked Him, and He has given you living water."

When people read this text, almost all readers emphasize the woman's immoral life. This was apparent when several times I asked students to read this text in class and ask who the Samaritan woman was. All said that she was a prostitute. When I asked them to look for the word prostitute in the text, they did not find it. But they attribute it to the sentence which says that the woman has five husbands and is therefore a prostitute and a sinner (de Klerk 2004, 167). ${ }^{10}$ This understanding might have been influenced by the interpretations of missionaries introduced to people in the mission area about sexual sins that should be avoided (Miguez 2004, 339-40). There is probability that it is related to the application of discipline or ecclesiastical tactics to members of the congregation, which consists of 3 cases, namely: murder, adultery and apostasy. But it could also be that the view of a Samaritan woman as a prostitute associated with five husbands, is influenced by culture, which views that a woman who has more than one husband (polyandri) as a woman is not right

${ }^{10}$ In the intercultural reading group by Jilles de Klerk, some text readers from Indonesia even said that the Samaritan woman tried to approach and tempt Jesus to be the next husband. 
and not good, and is seen as a prostitute. This is rather strange because in societies that practice polygamy marriages, they refuse if women have had several husbands, no matter whether the woman was abandoned (divorced or dead) by her previous husband. Thus, a man who has more than one wife is seen as great, while a woman who has several husbands is considered sinful. It is not explained in the text that this woman has been divorced five times, but that she once had five husbands. The absence of arguments about the private situation of women who once had five husbands has led to various explanations. ${ }^{11}$ Although the arguments can be accepted, in the Jewish tradition, having five husbands is not something normal. For this reason, the explanation linking five husbands with sexual sin cannot be interpreted and justified interpretatively. Jesus himself did not want to discuss the marital status of the woman, but only wanted to tell that He was not an ordinary human being who was just thirsty and asked to be given a drink. One of the allegations that is most likely to have the truth is (a) that she is a barren or not give birth to a child (Barker 2014, 364-65) and (b) she is divorced by her husband (Duff 2016, 99-100). This woman might also be a victim of a marriage of levirate like Tamar in Gen. 38 and the last man refused to marry her. See, for example, the history of a woman with Levirat seven times in Mk. 12: 18-27 and Deut. 25: 5 (Schottroff and Wacker 2007, 531; O’Day 1992, 296).

Also, an interpreter links it to the time of day when this woman goes alone to fetch water without being accompanied by other women. The text itself does not say the reason. But there

${ }^{11}$ In the classical interpretation these five husbands are associated with the five gods present in Samaria after their destruction in 722 SbM. Five gods were worshiped by the nation: Babylon, Kuta, Hamath, Awa and Sepharvaim (2 Kings 17: 30-31). This allegorical interpretation emphasizes the Samaritan apostasy which was the main reason for its destruction and in Jesus' conversation with the Samaritan woman they wanted to explain that they still lived far from the true God. 
are interpreters who say that as a famous sinner, he chose this time to avoid meeting other women who fetch water (Schottroff and Wacker 2007, 530; Thyen 2005, 245). Though people can take water at any time, including during the day, depending on the availability of water at home. If the water runs out during the day, then he will take water at that time, and not because of avoiding encounters with other people. The story of Rebekah who fetches water in the Well is also alone and is not accompanied by other women (Ge 24: 15-16), so is the story of Rachel who came alone to the well when she met with Jacob (Ge 29: $10)$. But there is no accusation that says they are bad women. The reason the five husbands and who are currently with her, is not her husband, and the reason for taking water during the day without being accompanied by other women, is a strong reason and is accepted by many to say that this woman is a prostitute or a sinner. So even though the context has changed, the understanding inherited from the missionaries is still held and there is no attempt to read or interpret the text in a new and creative way. Thus this text is still seen as a story about a prostitute who was saved by Jesus from his sexual sin.

If we look at the story from the narrator's perspective, the focus is not on the woman's personal life. Jesus was also not interested in discussing this woman's sexual life and did not condemn the woman in her reaction (see Jesus' subsequent response to this woman). In Jesus' conversation with women about his marriages, there was no attitude that criticized the woman's actions. Jesus also did not say: go and sin no more! It was a speech that he usually said when dealing with sinners. Jesus recognized the woman's faith and concentrated on the conversation about "wells and water". The tone of the judgment actually comes from readers and interpreters, and not from Jesus himself (Sim 2015, 2). 


\section{Criticism and Courage of Samaria Women}

It is said that at midday, when a Samaritan woman from Sikhar came to Jacob's well to fetch water, there was a man who was tired and sat by the well. He is Jesus. Samaria is not a destination but a trajectory to Galilee. Meeting with this woman is different from the conversation between Jesus and Nicodemus (John 3: 1-21), mentioned earlier in the Gospels. In the story with Nicodemus, Jesus speaks to a representative of the Jewish religion, the legal (official) Pharisees, who also has a name. Yet, at this time, He was speaking with an anonymous woman, a stranger from the area of Samaria, an area inhabited by Jewish enemies. The story of Jesus meeting this Samaritan woman is similar to many parts of the Old Testament, specifically the story of someone finding his wife at the well, such as Rebekah, Isaac's wife (Gen. 24:11, 15-16)., Rachel, Jacob's wife (Gen. 29), and Zipporah, Moses' wife (Ex 2: 11-22). All met their wives this way.

When the Samaritan woman came to the well in a bucket, Jesus spoke to her and asked, "Give me a drink"(Schottroff and Wacker 2007, 532). ${ }^{12}$ This made the woman uncomfortable, because such a request was very unusual. A man and woman alone in a well, far from the village, are a difficult and taboo situation. Coupled with the fact that a Jewish man started a conversation with a Samaritan woman is something strange even considered a scandal. A Jew, especially a man, never talked to a Samari$\tan$ woman. ${ }^{13}$ Thus there are two taboos here: men greet foreign

12 Jesus' act of asking for water reminds us of the encounter between Abraham's servants and Rebekah. Here Jesus as the messenger of God speaks to a Samaritan woman as the coming messenger of God.

${ }^{13}$ Many interpreters separate this from verse 27 . For a rabbi, it is not permissible to talk to a woman in public. It is related to sexual discipline. Men must be careful and avoid situations that can cause adultery or sexual relations. This is not a general prohibition on talking to women, but rather as 
women, and Jews who ask for water from a Samaritan woman (Schottroff and Wacker 2007, 532). Through this conversation, Jesus broke the line between men and women, between the chosen people and those who were rejected (O'Day 1992, 295). Here a reversal occurs: a Jew wants to get water from a Samaritan woman, and a man who wants to serve a woman.

The Samaritan woman realized that Jesus was a Jew, so she asked, "How can you ask for water from me, while you are a Jew, and I am a Samaritan woman?" He refers to the religious relationship between Jews and Samaria, social relations between men and women. It is interesting that this woman is not silent, but is against what Jesus said. Her answer to the difference "a Jewish man and a Samaritan woman" shows a clear separation between him and Jesus. Of course he can give Him water, but she points to social and religious barriers between them. She mentioned rumors of hostility between Jews and Samaritans and felt that Jesus' request was incorrect or strange. The oddity was also felt by the students when they arrived at the well (4:27) and saw Jesus talking to a woman. A Jewish prophet may not talk to women in public places. Did the gospel writer deliberately emphasize this woman's attitude as a representation of the group of Samaria who is often called half Jewish? Usually in the gospel tradition, it was the Jews themselves who were reluctant to befriend the Samaritans. From this normal attitude, the gospel writer wants to emphasize the change in attitude from Jesus on the one hand and raise the suspicion of the Samaritans on the other. It should also be noted that the attitude of the Samaritan woman who was not rigid in giving an answer, "Do you, a Jew, ask me to drink, a Samaritan?” (Card 2014, 68-69).

Through the question of the Samaritan woman, the narrator wanted to show the prohibitions and views of the Jews but this

an appeal to control one's own sexual temptations. 
woman did not pay attention to the prohibition. This is demonstrated by his willingness to talk with Jesus. Jesus also did not defend himself. The courage and freedom of this woman is extraordinary, because she does not know who Jesus is. He moves from alienation to society, from degrading social and religious contexts, to dialogical relations. This Samaritan woman not only fulfilled Jesus' request but also accepted His offer to give her living water (verse 10). Although open acceptance of the offer has been given to Jesus, but he himself still does not fully understand Jesus personally, his interlocutor. That happened because Jesus himself did not directly tell who he really was (Collins 2013, 302). Nevertheless, he asked, "Are you more than our father Jacob, who gave us this well?" She pointed to her religious tradition and learned of history when Jacob discovered water in this place with his children and animals. ${ }^{14}$

Jesus' response was "Go, call your husband, and come back here," does not indicate that Jesus really expected to meet with her husband or question her sexual life. But this order was only a strategy to show the woman about His divine omniscience (Thyen 2005, 253). Jesus' knowledge of the woman's personal life (which has five husbands) has made her realize that Jesus was a Prophet (verse 19) and a Messiah (verse 29), who would free her from her suffering (Levirat's marriage) (Schottroff and Wacker 2007, 531 $)^{15}$. In other words, Jesus' question to the woman was aimed at showing who He was, a Prophet, who was able to see and know everything, and not to show her sexual sin. This is evident from the response of the woman who said, "God,

${ }^{14}$ As an analogy with the story of the gift of Manna, this also applies to this well, where it was not Jacob who gave living water, but My Father gave the real fountain of life.

${ }^{15}$ Jesus did not criticize marriage in general, but criticized its social use against the exploitation and dependence of women. 
it is real now to me, that You are a Prophet" (verse 19). ${ }^{16}$ This woman's confession was the beginning of a new introduction to Jesus. If at first he greets Jesus as a Jew, then after the conversation has taken place, he greets Jesus as Lord and prophet (Sturdevant 2015, 122). In addition, Jesus' question shows that this was the time when Samaria's women could see Jesus with new eyes (O'Day 1992, 296).

Next we see that the Samaritan woman challenges and even destroys social barriers and the status quo that has existed so far, as she asks questions about the correct place of worship (verses 19-20). According to the Samaritan Scriptures, the Pentateuh, there is only one place of worship. They considered Mount Gerizim to be a majestic and elegant mountain, because Noah and Abraham had offered sacrifices there. The Samaritans consider Mount Gerizim as their sacred mountain, as a place of worship where God is present, and as sacred as the Temple in Jerusalem, which was a place of worship for Jews (Thyen 2005, 242; O’Day 1992, 295). ${ }^{17}$ This woman knows her religious traditions well. He said, "Our ancestors worshiped on this mountain, but you say that Jerusalem is the place where people worship." By citing her ancestors, he sought legitimacy for the worship of the Samaritans, which was contrary to the worship of the Jews. This represented the tradition of their ancestors about the practices and dogmas of the Jews of Jesus' day. The Samaritan tradition is

16 The statement in verse 19 needs attention. First, the change in the greeting "God" (Kurie) directly addressed to Jesus; secondly, theoreo verb (I see) in the LAI translation: real, always positive in the Gospel of John even though it is not an emphasis, cf. Yoh 6: 2.19.40.62; 12:45. A recognition that arises from awareness and recognition confronted with reality, in this case related to the identity of Jesus who is called a prophet.

17 The Samaritans built and worshiped at the temple located on the hill of Gerizim. John I Hyrcan tried to conquer the province of Samaria (first attempt in 128 BC), and destroyed the Temple of Gerizim and the city of Shem, which was not rebuilt. 
based on the authority of her ancestors. Here, it appears that this woman was a theologian who was dealing with a Prophet and discussed religious issues with Him. This topic is what brought it in the context of its own tradition, where it is rooted. When she talked about the possibility of Jesus being their Messiah, she did this as a Samaritan woman (not a Jewish person or woman) and not according to Jewish faith and ideas. ${ }^{18}$

Furthermore, in verses 21-24 a change in the flow of conversation occurs. Jesus shifted the focus of the conversation about places of worship to both Jews (Jerusalem) and Samaria (Gerizim). Jesus' response that true worshipers will worship the Father in Spirit and truth. Worship for Jesus no longer depends on location or place (read: religious traditions) but on new attitudes in the Spirit and truth. Jesus as a source of spirit facilitated such worship. In that sense and meaning Jesus' statement as living water is becoming increasingly clear. The writer of the Gospel of John in chapter 7 captured Jesus' statement as living water again: 37-39. These three verses explain that Jesus as the source of living water and who believes in him will flow from the streams of living water (Fowler and Strickland 2018, 79-80). What became the pride of Jews and Samaria according to the Gospel of John no longer seemed justified in Jesus. In time Jesus' statement in verse 23 is still futuristic, "to come" in the sense of an eschatological context (Rainbow 2014, 77).

The shift in the attitude of the Samaritan woman from unbelief to faith in Jesus shows that she is a person who practices her faith. Although he initially disagreed with Jesus, he heard Jesus' words and brought others to Him through his testimony.

${ }^{18}$ Jesus' words which say that people no longer worship "both on this mountain and in Jerusalem," and that will happen where people worship "in spirit and truth", are often understood as something that contrasts with all rituals bound to a particular place and time, and with worship related to spiritual cults. 
He left his water jug and went to the city, meeting his tribesmen to tell them about his encounter with Jesus at the well. He also invited them to come meet with Jesus. In verse 39 it is said that many people believed in Jesus because of the words of the woman, who testified ... If we understand the task of an Apostle as someone who brings the gospel message or testifies about Jesus to others, then the Samaritan woman can be called an Apostle first. Thus it can be said that the Samaritan woman was a young woman, a witness, and an apostle, like John, Andrew, Peter.

Next it appears that both Jesus and the Samaritan woman asked for water and both changed through the encounter of God. Jesus became the Messiah for the Samaritans and for the messenger of God, who told the Samaritans that Jesus was the Savior of the world (verse 40). Living water which removes thirst, is transformed into a human whose source of water is eternal life. This formulation seems ambiguous. On the one hand, eternal life is given to recipients of water. On the other hand, this experience makes humans themselves at the same time become "a source of water" for others. That is, if a person participates in eternal life through faith in Jesus, at the same time he becomes a leader who directs others to this source of eternal life in Jesus (Wickelns 1998, 82). There was a change from a woman who was thirsty for living water, to a woman who gave living water. He will not be thirsty anymore, and no longer works to fetch water, but becomes a source of living water. It cannot become a source of living water if it continues to live in its dependence on men who use it. With the answer: I don't have a husband, at that time he was making a decision not to depend on men.

\section{Closing Remark}

From what has been explained, it can be concluded that this Samaritan woman was not a prostitute, but a woman who was great because of her openness, confession, initiative, and decisive 
actions (Schottroff and Wacker 2007, 533). She was not afraid of Jews and Samaritans. She is not a passive recipient who accepts all of Jesus' testimonies without asking. Her theological background, her own interests, and her spontaneous actions to appear as witnesses in the city are very important actions. She was committed to the message of Jesus, without the consent or permission of others, especially her people. She also has the ability to engage in serious theological conversation with Jesus. It might even be said that she was the first person in the Gospels to engage in a serious theological conversation with Jesus (O'Day 1992, 296).

The view in any patriarchal culture that women are intellectually inferior, socially marginal, impure, insignificant in culture, and therefore they are unable to guide and lead, is a false or mistaken view. Samaria woman is an example of a woman who does not pay attention to the prohibitions and limitations of culture, gender and religion. She is not passive, but active and voiced.

Learning from the story of the Samaritan woman, women need to have the confidence to act actively and not remain silent, including in situations of oppression and discrimination. Women need to speak the truth and dare to oppose the restrictions and injustice done because of their womanhood. The church also needs to renew its teachings and rules to provide wider opportunities for women in church service. Men and women are equal creations and they can work together and support one another in church services.

\section{Bibliography}

Ashton, John. 2014. The Gospel of John and Christian Origins. Minneapolis: Fortress Press.

Barker, Margaret M. 2014. King of the Jews: Temple Theology in John's Gospel. London: SPCK. 
Brown, Sherri. 2015. "Water Imaginary and the Power and Presence of God in the Gospel of John." Theology Today 72 (3): 289-98.

Card, Michael. 2014. John: The Gospel of Wisdom. Illinois: Downer Grove.

Collins, Adela Yarbrp. 2013. "Epilog." In John's Gospel and Intimations of Apocalyptic, edited by Catrin H. Williams and Christoper Rowland. London; New Delhi; New York; Sydney: Bloomsbury.

Daly, Mary. 1985. Beyond God the Father: Toward a Philosophy of Women's Liberation. Boston: Beacon Press.

Day, Janeth Norfleete. 2002. The Woman at the Well: Interpretation of John 4:1-42 in Retrospect and Prospect. Leiden/ Boston/Koln: Brill.

Duff, Nancy J. 2016. "The Ordination of Women: Biblical Perspectives.” Theology Today 73 (2): 94-104.

Engberg-Pedersen, Troels. 2017. John and Philosophy: A New Reading of the Fourth Gospel. Oxford: University Press.

Fiorenza, Elisabeth Schüssler. 1995a. Bread Not Stone. Boston: Beacon Press.

—. 1995b. Untuk Mengenang Perempuan Itu. Jakarta: BPK Gunung Mulia.

- 2001. Wisdom Ways: Introducing Feminist Biblical Interpretation. Maryknoll, New York: Orbis Books.

Fowler, William G, and Michael Strickland. 2018. The Influence of Ezekiel in the Fourth Gospel: Intertextuality and Interpretation. Leiden/Boston: Brill.

Gorman, Michael J. 2017. "John's Implicit Ethic of Enemy-Love.” In Johannine Ethics: The Moral World of the Gospel and Epistle of John, edited by Sherri Brown and Christoper W. Skinner, 135-58. Minneapolis: Fortress Press. 
Kasper, Walter. 2009. Lexikon Fuer Theologie Und Kirche. Fraeiburg-Basel-Wina: Herder.

Klerk, Jilles de. 2004. “Through Different Eyes: Indonesian Experiences with an Intercultural Reading of John 4." In Through the Eyes of Another, edited by Hans de Wit, Louis Jonker, Marleen Kool, and Daniel Schipani. Amsterdam: Institute of Mennonite Studies Vrije Universiteit.

Kristianto, Stefanus. 2019. "Woman and Rape Case: Considering the Second Antithesis." Asian Journal of Theology 33 (1): 34-46.

Lim, Sung Uk. 2010. “Speak My Name. Anti Colonial Mimicry and the Samaritan Woman in John 4:1-42." Union Seminary Quarterly Review 62 (3): 35-51.

Listijabudi, Daniel K. 2019. "Pembacaan Lintas Tekstual. Tantangan Ber-Hermeneutik Alkitab Asia (2)." Gema Teologi: Jurnal Teologi Kontekstual 4 (1).

Marc-Andre, Argentino, and Guy Bonneau. 2016. "The Function of Social Conflict in the Gospel of John." In The Origins of John's Gospel, edited by Stanley E. Porter and Hughson T. Ong, 124-41. Johannine Studies 2. Leiden/Boston: Brill.

Miguez, Nestor. 2004. "Reading John 4 in the Interface Between Ordinariand Scholarly Interpretation." In Through the Eyes of Another, edited by Hans de Wit, Louis Jonker, Marleen Kool, and Daniel Schipani. Amsterdam: Institute of Mennonite Studies Vrije Universiteit.

O’Day, Gail R. 1992. “John.” In The Women's Bible Commentary, edited by Carol A. Newsom and Sharon H. Ringe. Louisville, Kentucky: Westminster/John Konx Press.

Powery, Emerson B. 2015. "Lost in Translation. Ethnis Conflict in English Bibles' - The Gospel, 'Race' and the Common English Bible. An Introduction and Exploratory Conversation." Ex Auditu 31: 154-68. 
Rainbow, Paul A. 2014. Johannine Theology: The Gospel, The Epistle and The Apocalypse. Illinois: Downer Grove.

Russel, Letty M. 1998. "Kata Pengantar: Membebaskan Firman.” In Perempuan \& Tafsir Kitab Suci, edited by Letty M. Russel. Yogyakarta - Jakarta: Kanisius - BPK Gunung Mulia.

Schottroff, Luise, and Marie-Theres Wacker. 2007. Kompendium Feministische Bibelauslegung. Gütersloh: Gütersloher.

Sim, Ronni. 2015. “The Samaritan Woman in John 4.” Journal of Translation 11 (1): 1-34.

Sturdevant, Jason S. 2015. The Adaptable Jesus of the Fourth Gospel: The Pedagogy of the Logos. London/Boston: Brill.

Thyen, Hartwig. 2005. Das Johannes Evangelium. Handbuch Zum Neuen Testament 6. Tübingen: Mohr Siebeck Verlag.

Trible, Phyllis. 1982. "Feminist Hermeneutics and Biblical Studies." Christian Century 99.

Wickelns, Ulrich. 1998. Das Evangelium Nach Johannes. NTD Band 4. Göttingen: Vandenhoeck \& Ruprecht. 